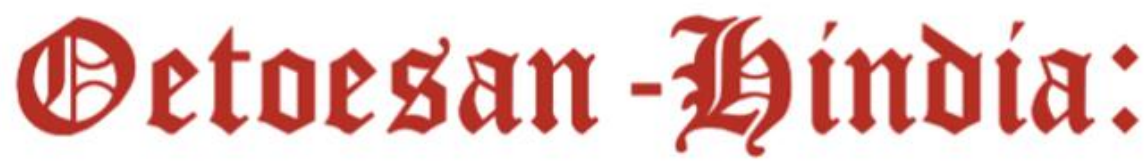 \\ Telaah Pemikiran Kebangsaan
}

Volume 1 No 1 Tahun 2019 Hlmn. 33-42

Artikel Masuk: 28 Agustus 2019 | Artikel Diterima: 14 September 2019

\section{Jang oetama yang hidup}

\author{
Aji Dedi Mulawarman \\ Jurusan Akuntansi Universitas Brawijaya, Jl. Veteran, Malang, Indonesia, 65145 \\ *ajidedim@ub.ac.id \\ *surel korespondensi: ajidedim@ub.ac.id
}

\begin{abstract}
Abstrak
Tulisan ini bertujuan untuk menghidupkan kembali semangat H.O.S. Tjokroaminoto untuk menjadikan Indonesia sebagai pusat peradaban dunia. Penulis menelusuri sepak terjang Pak Tjokro berupa pemikiran dan aksi yang menghasilkan dua kata kunci, yaitu Hijrah dan Zelfbestuur. Indonesia membutuhkan Hijrah untuk mencapai Zelfbestuur mengingat betapa deras dan menyesatkannya arus peradaban. Indonesia berdikari dapat dicapai dengan Mosi Kebangkitan Nasional Baru Berjiwa Jang Oetama yang Selalu Hidup.
\end{abstract}

Kata Kunci: Indonesia Berdikari; Zelfbestuur; Hijrah; Tjokroaminoto

\begin{abstract}
This paper aims to revive the spirit of H.O.S. Tjokroaminoto to make Indonesia the center of world civilization. The author traces the actions of Mr. Tjokro in the form of thoughts and actions that produce two keywords, namely Hijrah and Zelfbestuur. Indonesia needs Hijrah to reach Zelfbestuur given how swift and misleading the flow of civilization. Indonesia's self-sufficiency can be achieved with the New Life Awakening National Movement Jang Oetama.
\end{abstract}

Keywords: Indonesian Self-Reliance; Zelfbestuur; Hijrah; Tjokroaminoto

Buku Hidup pasti berbeda dengan Buku Mati. Jika Buku Mati setelah selesai dibaca hanya menjadi pajangan setelah ditulis, dicetak, dan dibaca, maka Buku Hidup dapat menginspirasi dalam bentuk konkrit. Contohnya Jang Oetama yang mejadi bibit terbentuknya Yayasan Rumah Peneleh, tempat para aktivis lintas jaman dan berbagai bidang untuk berdiskusi membawa nilai-nilai kebaikan dan semangat kebangsaan, kemandirian, dan religiositas HOS Tjokroaminoto. Kegiatan pengaderan dan konsolidasi umat tertuang dalam berbagai kegiatan, di antaranya Pendidikan Dasar Nasional (Diksarnas) Aktivis Peneleh, Sekolah Aktivis Peneleh Regional (SAPR), Peneleh Youth Volunteer Camp (PYVC), Sekolah Relawan Riset (RR), Seminar 


\section{Jang oetama yang .... \\ Mulawarman, A. D.}

Kebudayaan, hasil kerjasama Yayasan dengan perguruan tinggi dalam dan luar negeri. Buah pemikiran baik dari berbagai kegiatan Yayasan, maupun dari diri para aktivis diwadahi dalam beberapa jurnal yaitu International Journal of Religious and Cultural Studies (IJRACS) dan Oetoesan Hindia: Telaah Pemikiran Kebangsaan, media keberpihakan Peneleh News serta Website Rumah Peneleh (http://rumahpeneleh.or.id) hingga konferensi internasional pada 16-17 Oktober 2019 di Surabaya (http://conference.rumahpeneleh.or.id) dan di luar negeri yang berkerjasama dengan School of Management Science Varanasi, India, pada 23-24 Februari 2019. Berkat buku ini pula, silaturahmi terjalin dengan tokoh-tokoh lokalnasional seperti KH. Zawawi Imron, Emha Ainun Nadjib, KH Mustofa Bisri, Ade Komaruddin, Teguh Esha, Anhar Gonggong dan lainnya, akademisiakademisi kampus, serta tokoh Syarikat Islam (SI) dan Syarikat Islam Indonesia (SII), seperti Aulia Tahkim Tjokroaminoto, Muflich Chalif Ibrahim, Hamdan Zoelva, dan banyak lainnya.

Oleh karena itu, penulis terpantik untuk menulis tambahan untuk Jang Oetama, semenjak terbit pada 20 Mei 2015 di Hotel Bidakara Jakarta dan selama ini ditutup dengan Bab 7, yaitu Catatan Akhir. Ramainya permintaan bedah buku, cetakan buku, hingga seminar mengenai jejak kehidupan dan pemikiran HOS Tjokroaminoto, hingga penjualan buku edisi asli sampai dengan bajakan tersedia di lapak buku yang tersebar di Pulau Jawa mencerminkan betapa "hidup" buku ini. Jang Oetama itu sendiri dibangkitkan oleh HOS Tjokroaminoto saat membangkitkan Sarekat Islam. Beliau mengambil uswah sakral Rasulullah SAW, Ummati-Ummati-Ummati sebagai implementasi Surat Ash-Shaff, bahwa keutamaan berjuang dalam sebuah barisan kokoh dengan mengerahkan segenap harta dan jiwa. Menarik untuk dibahas, bahwa Pak Tjokro yang seorang ningrat dan lulusan sekolah Pamong Praja di awal abad ke 20 dapat berubah menjadi pejuang rakyat dan kemerdekaan dengan ruh Jang Oetama?

\section{PEMIKIRAN}

Hidupnya Jang Oetama di masa HOS Tjokroaminoto. Kondisi memprihatinkan pada masa Pak Tjokro adalah manusia di Nusantara memiliki Mental Pasrah Rakyat dan Mental Ambtenaar. Mental Pasrah Rakyat adalah mental tanpa daya rakyat karena kehilangan upaya, jiwa raga, harta, tanah, dan kehidupan sosial karena represi berkesinambungan sejak Politik Cultuurstelsel pada 1830 sebagai buah kemenangan licik Belanda atas Pangeran Diponegoro dalam Perang Jawa 1825-1830. Mental Ambtenaar merupakan mental yang dimiliki pejabat negeri, bangsawan, serta para saudagar yang mementingkan diri sendiri dan pengakuan sosial saja. Golongan ini oleh Sultan Agung Hanyokrokusumo juga disebut Cecunguk atau priyayi bermental Londo Bulak, Boyo Putih. Mereka memilih menginjak bangsa sendiri (Wong Kromo) dan menjilat penjajah (Londo Asli). 
Pak Tjokro menyiapkan kemerdekaan dengan cara meninggalkan zona nyaman dari priyayi menjadi Wong Kromo serta melakukan beberapa gerakan. Pertama, politik konsolidasi organisasi yaitu gerakan berjiwa kebersamaan. Organisasi menjadi alat dalam mencapai nilai kejuangan, bukannya organisasi apalagi kepentingan diri yang menjadi tujuan. Hal ini tercermin pada penghilangan kata Dagang pada Sarekat Dagang Islam menjadi Sarekat Islam karena perdagangan hanyalah satu cara untuk menyatukan ummat. Perombakan simbol ini berhasil membuat 2,5 juta orang bergabung menjadi anggota dari tujuh tahun sebelumnya sejumlah 2000 anggota. Hal ini merupakan rekor untuk organisasi massa pada masa itu. Kemudian hijrah dilanjutkan dengan pengubahan nama menjadi Partai Sarekat Islam (PSI), dan kemudian Partai Sarekat Islam Indonesia (PSII).

Kedua, gerakan sosial-ekonomi dilakukan melalui pembentukan koperasi di cabang Sarekat Islam seluruh Indonesia, serta bidang pendidikan dengan mendirikan Moslem Nationaal Onderwijs dan kini masih ada Sekolah Tjokroaminoto dan Perguruan Tinggi di berbagai daerah di Indonesia, sektor pertanian, pembelaan terhadap hak-hak kepemilikan, blusukan, dan penyadaran komunitas melalui kebudayaan melalui gerakan Djawa Dwipa pada 1917, dan pergerakan organisasi, sampai kajian Keislaman-PolitikSosial-Budaya.

Ketiga, penyebaran ideologi sosialisme islam melalui media dan diskursus pada awalnya tentang pentingnya nasionalisme dan Islam, kemudian melucuti Komunisme pada anggota SI, lalu menulis Islam dan Sosialisme pada 1924, dan puncaknya adalah Memeriksai Alam Kebenaran pada 1928 yang disampaikan pada Kongres Jong Islamiten Bond ke-4, kemudian diturunkan menjadi Tarikh Agama Islam, Program Asas dan Program Tandhim beserta Tafsirnya tahun 1931. Memeriksai Alam Kebenaran menegaskan bahwa nilai-nilai Islam harus menjadi ruh dalam setiap gerakan keumatan. Shalat menjadi pusat gerakan kemanusiaan demi menuju Insan Kamil.

Keempat, melakukan gerakan relasional, dengan menjalankan agenda nasional, diantaranya aktif dan menyampaikan Mosi Tjokroaminoto di Volksraad (Dewan Daerah) bersama Politieke Concentratie, menggagas gerakan kebudayaan Djawa Dwipa, membentuk Tentara Kanjeng Nabi Muhammad, mencetuskan terlahirnya federasi nasional PPPKI (Perhimpunan-Perhimpunan Politik Kebangsaan Indonesia) tahun 1927, kemudian Majelis Oelama pada 1928 yang merupakan cikal bakal Majelis Ulama Indonesia (MUI). Pada tataran internasional, Pak Tjokro menjadi ketua Kongres Al-Islam tahun 1922, kemudian diundang bersama K.H. Mas Mansyur untuk mengikuti Kongres Umat Islam se-Dunia (Muktamarul Alam Islamy Farulhim bi Syarkiyah) di Mekkah pada 1926.

Hijrah Menuju Zelfbestuur!!! Semangat dan kejuangan Pak Tjokro dapat dirangkum dalam dua kata, yaitu Hijrah dan Zelfbestuur. Zelfbestuur atau Pemerintahan Sendiri dikumandangkan pertama kali oleh Pak Tjokro di 
depan puluhan ribu peserta Rapat Akbar (Vergadering) se-Nusantara alunalun kota Bandung pada 18 Juni 1916. Pak Tjokro muda berani mengumandangkan kata Kebangsaan (Natie) dan Pemerintahan Sendiri (Zelfbestuur) yang jika digabungkan menjadi Kemerdekaan Nasional untuk yang pertama kalinya di khalayak. Rapat akbar ini sendiri merupakan acara pada hari kedua dari delapan hari Kongres Nasional Pertama Central Sarekat Islam (1e Nationaal Congres Centraal Sarekat Islam) pada tanggal 17 sampai dengan 24 Juni 1916 yang dihadiri ratusan orang perwakilan dari 80 cabang (afdeling) Sarekat Islam yang mewakili 360.000 anggota, dari total 800.000 anggota. Selain itu, ada pawai keliling di titik keramaian Kota Bandung, Pesta Rakyat, dan Kegiatan Kongres Central Sarekat Islam. Semangat Pak Tjokro ini kemudian menggema di berbagai lapisan masyarakat di Jawa, Madura, Sumatera, Kalimantan, Sulawesi, dan Ambon. Sarekat Islam merupakan organisasi pertama yang modern dan memiliki anggota terbesar mencapai 4 juta orang per tahun 1919 menurut catatan organisasi, sedangkan catatan Pemerintah Belanda hanya mencatat jumlah 2,5 juta anggota. Boedi Oetomo sebagai simbol gerakan priyayi pada jaman itu hanya mempunyai 10.000 orang anggota pada 1909, sedangkan Partai Komunis Indonesia memiliki 250.000 orang pada 1938. Sosiolog Belanda W.F. Wertheim menyatakan kekagumannya terhadap Gerakan Raksasa SI melalui pernyataannya (Maarif, 2006: 82).

"Salah satu fenomena paling menarik perhatian adalah ekspansi yang cepat dari gerakan Sarekat Islam di kalangan petani Jawa. Jumlah besar yang berhasil dikumpulkan organisasi ini dalam beberapa tahun (disebut di atas dua juta) merupakan tanda bahwa ikatan-ikatan kolektif baru suatu jenis organisasi sejalan dengan suatu kebutuhan mendalam yang dirasakan di antara banyak desa. Corak keagamaan dari ikatan yang baru ini pada level bawah di kalangan petani mengajukan appeal kepada sistem nilai yang ada. Sebagai gerakan pranasionalis, Sarekat Islam pada waktu yang sama memberikan saluran kepada suatu keinginan umum di kalangan petani untuk mengidentifikasi dirinya dengan mereka yang mempertahankan sistem nilainya sendiri melawan pemerintah kolonial dan wakil-wakilnya."

Gerakan SI dipandang lebih maju daripada yang lain karena mampu menembus lintas daerah dengan basis keyakinan Islam sehingga dapat dikatakan sebagai persatuan umat Islam di Nusantara yang pada saat itu masih dijajah Belanda. Pak Tjokro sendiri mengungkapkan hubungan ini.

"Kita mencintai bangsa kita dan dengan ajaran agama kita (Islam) kita berusaha sepenuhnya untuk mempersatukan seluruh atau sebagian terbesar bangsa kita." 
Berbeda dengan organisasi lain, misalnya Boedi Oetomo yang berbasis Jawa $^{1}$ dan Madura ${ }^{2}$, SI mampu menembus batas daerah. Seiring sejalan dengan semangat nasionalisme yang beliau usung, Pak Tjokro bahkan memilih menanggalkan gelar "Raden Mas" yang menurutnya biasa dan memilih dikenal dengan Haji Oemar Said Tjokroaminoto karena gelar "Haji" yang begitu universal dan merupakan simbol perlawanan terhadap dominasi Belanda. Pidato Pak Tjokro untuk membangunkan kesadaran sekaligus keberanian mengambil kembali hak-hak genuine, genetis dan hidup di atas bumi nusantara negeri tumpah darah sendiri, dalam satu bahasa, kemerdekaan umat atau kemerdekaan kebangsaan (nationale vrijheid) ${ }^{3}$ di berbagai acara ampuh melawan kuasa Belanda melalui gerakan nasional kerakyatan. Pak Tjokro juga mengritisi bangsa sendiri yang merasa minder akibat penjajahan Belanda sehingga merasa hina dan bahkan menghinakan diri sendiri.

Gerakan radikal Pak Tjokro melalui SI/CSI ini sebenarnya merombak struktur terdahulu yang lebih fokus pada perlawanan dagang dan ekonomi. Sarekat Dagang Islam yang digagas oleh H. Samanhoedi dan pengurus yang lain pada 16 Oktober 1905 di Surakarta berubah menjadi Sarekat Islam pada 1906 dan kemudian menjadi lebih luas cakupannya setelah Pak Tjokro diminta bergabung pada 1912 dan menjadi penggerak utama. Keberanian Pak Tjokro melawan Belanda di tengah masyarakat Jawa yang identik dengan milenarism, dianggap sebagai Sang Heru Tjokro, Ratu Adil yang ditunggu-tunggu ${ }^{4}$. Nama Tjokroaminoto dianggap sebagai perwujudan kebenaran ramalan Jayabaya dari Kediri (1135-1157) yang menyatakan saat negara terjadi gonjang ganjing dan penindasan terhadap rakyat, maka akan muncul sosok penyelamat, yaitu Ratu Adil Heru Tjokro. Rakyat pada saat itu sampai berbondong-bondong ingin menemui atau sekedar melihat dari dekat di setiap acara yang diadakan oleh SI.

Hidupnya Jang Oetama Pasca HOS Tjokroaminoto. Kita tidak cukup mengulang-ngulang kisah Pak Tjokro di tengah arus peradaban yang dapat

\footnotetext{
${ }^{1}$ Berdasarkan Surat Edaran Tentang Berdirinya Boedi Oetomo tanggal 20 Mei 1908 sebagaimana dicatat oleh Sowarno, Sekretaris I, dari hasil Pengumuman Afdeling Bestuur Boedi Oetomo, Weltevreden, 1908 (Soeharto \& Ihzan, 1981) bertujuan untuk "mengusahakan persatuan kaum Bumiputra yang sedapat mungkin bersifat umum, sehingga akhirnya akan tercapai terbentuknya suatu Persatuan orang Jawa pada Umumnya...".

${ }^{2}$ Tirtoprodjo (1961: 12) menunjukkan tujuan Boedi Oetomo sebagai organisasi bukan hanya untuk kepentingan Jawa saja, tetapi juga untuk Madura. Sebagaimana tujuannya disebutkan untuk "de harmonische ontwikkeling van land en volk van Java en Madura" yang artinya: kemajuan yang harmonis untuk nusa dan bangsa Jawa dan Madura.

${ }^{3}$ Tjokroaminoto (1958: 30).

4 Untuk perbandingan lihat Lowensteyn (2005) yang mengutip McVey (1963) mengatakan: The earlier mentioned concept of Ratu-Adil was prominent in the Sarekat Islam where Tjokroaminoto was regarded by many of his followers as the "saviour prince".
} 
menjadi jauh menyimpang dari gagasan para The Founding Father yang juga menjadi murid Sang Guru Bangsa, yaitu Pancasila. Pancasila pada saat itu menjadi simbol perlawanan kapitalisme, liberalisme, dan komunisme yang berevolusi menjadi Kapitalisme Kapitalisme Religius, Liberalisme Baru, Komunisme Baru, Posmodern, Manusia Dewa, Manusia Tuhan dan entah apa lagi.

Penulis sering mengungkapkan "jangan jadi bebek-bebek peradaban" di berbagai forum sebagai peringatan untuk menjadi kritis terhadap zona nyaman arus peradaban yang bisa jadi bertentangan dengan paham kita. Pada era 70-an, revolusi hijau diikuti dan menghasilkan tanah mati dan kerusakan alam. Kini muncul corporate social responsibility (CSR), good corporate governance (GCG), sustainable development goals (SDG's), demokrasi liberal, revolusi industri 4.0, dan lain-lain, bahkan jika perlu kita ngikut The Grand Pacific atau The New Silk Roads, layaknya sampah yang ikut dalam arus sungai peradaban.

Jika kita mau tegas dan menuju kejayaan negeri yang sesungguhnya, tidak perlu ada Trah Genetis, Biologis, maupun Ideologis. Yang ada adalah Kebangkitan Nasional Berjiwa Jang Oetama. Pak Tjokro menyatakan dalam pidatonya di vergadering CSI 1916, yaitu:

“...bilamana kita memperoleh Zelfbestuur yang sesungguhnya, artinya bila tanah air kita, kelak menjadi suatu negeri dengan pemerintahan sendiri, maka seluruh lapisan masyarakat semuanya akan menuju ke arah dan bersama-sama memelihara kepentingan kita bersama, dengan tidak pandang bulu, bahasa, bangsa maupun agama... dengan segenap kekuatan yang ada dan menggunakan segala tenaga serta daya upaya kita melalui jalan yang benar dan lurus..."

Musuh yang dihadapi kini merupakan evolusi Kolonialisme Fisik, cultuurstelsel-liberal-ethics Belanda, yaitu Kolonialisme Kesemestaan, Cultuurstelsel Global yang menggeser peran buruh pabrik dengan mesin produk global, Neoliberalisme Global, dan Etika Global. Tidak berhenti hanyapada penggeseran buruh, tapi asal muasal buruh tersebut yang sebenarnya merupakan migran desa dari daerah pertanian potensial. Hal ini dibuktikan dengan sensus 2013 yang menunjukkan dari 25 juta rumah tangga petani, mayoritas terdiri dari perempuan $(76,84 \%)$ dan petani gurem $(55,33 \%)$. Petani tidak berdaulat di negara sendiri, namun hanya sebatas pekerja dan penyedia lahan untuk perusahaan multinasional atas nama kebutuhan pangan nasional.

Oleh karena itu, pemikiran Sang Guru Bangsa dapat diterapkan sebagai bagian dari Penyadaran Nusantara berkemandirian, Berdiri di atas Kaki Sendiri. Pemerintah dapat memfasilitasi mekanisme ekonomi dengan pembentukan koperasi yang diagendakan sebagai program nasional lewat APBN menjadi Koperasi Multi Nasional. Selama ini yang terjadi adalah 
koperasi dibiarkan berusaha sendiri sebagai bagian dari usaha mikro, kecil dan menengah sehingga di-framing sebagai badan yang takkan menjadi besar.

Dunia pendidikan juga butuh diluruskan pada Akhlaqul Karimah dan Keikhlasan atas nama Allah karena adanya Etika Global atau liberalisasi pendidikan yang menanamkan Etika Utilitarian (Transaksional) dan Virtue (Etika Universal) bebas agama pada seluruh struktur kurikulum, pembelajaran semua jenjang pendidikan dan profesi. Etika Global telah masuk ke dalam buku-buku ajar dan secara tidak sadar, nilai-nilai yang dipelajari oleh manusia Indonesia adalah mementingkan diri sendiri (antroposentris), meniru kebebasan ala Barat, mementingkan keuntungan dan transaksional. Inilah yang terjadi di Indonesia pada saat ini, korupsi marak! Manusia Indonesia mementingkan diri sendiri daripada kepentingan bersama. Tanpa keikhlasan, kepentingan yang bersifat transaksional akan terus ada, baik dari tingkatan self interest, social interest, dan global interest. Interest merupakan riba yang sebenarnya, yang merusak umat seperti yang disampaikan dalam Q.S. Al Baqarah ayat 275:

"Orang-orang yang memakan riba tidak dapat berdiri melainkan berdirinya orang yang kemasukan setan karena gila."

Keikhlasan tertinggi ada pada dalam jiwa Tjokroaminoto untuk Islam Kesemestaan Baru, yaitu ada cinta untuk memperbaiki negeri dengan kerakyatan, kecintaan kepada Allah, Mahabatullah, yaitu Zelfbestuur Baru, Zelfbestuur Tauhid, Nasionalisme Kesemestaan Berketauhidan. Untuk menuju Zelfbestuur, Hijrah diperlukan sesegera mungkin dengan melalui empat bagian, yaitu Sejarah, Demokrasi, Ekonomi, dan Kebudayaan.

Pertama, hijrah kesejarahan. Pada 16 Oktober 1905, 110 tahun lalu, H. Samanhudi membentuk organisasi modern pertama di Indonesia bernama Sarekat Dagang Islam yang lebih menusantara daripada Budi Utomo yang hanya untuk Jawa dan Madura. Nyatanya, justru 20 Mei 1908 yang dianggap sebagai Hari Kebangkitan Nasional. Hal ini menunjukkan sejarah dipengaruhi mental orientalis sebagaimana yang dianut Belanda yang telah mengaburkan peran wali songo dan menghancurkan jejak situs kerajaan Demak demi menghilangkan peran sentral Islam di Negeri ini. Jika kita masih mengakui Soekarno sebagai salah satu pendiri bangsa, maka kita harus meyakini pula bahwa kita tidak boleh melupakan sejarah seperti ditegaskan beliau JAS MERAH, jangan sekali-kali melupakan sejarah!

Soekarno merupakan murid yang sangat mencintai HOS Tjokroaminoto sebagai guru, ditandai dengan ucapannya "Cerminku adalah Tjokroaminoto". Ini sama artinya dengan Tjokroaminoto adalah guru para pemimpin negeri, yang merupakan pejuang yang paling tangguh, penggerak Sarekat Islam yang semula bernama Sarekat Dagang Islam. Maka, seharusnya tonggak kebangkitan negeri adalah 16 Oktober 1905, bukan 1908. Sejarah ini harus diluruskan agar kita tidak menjadi musuh bangsa sendiri, Londo Bulak atau 
manusia Indonesia berkulit sawo matang berotak Barat seperti yang disebut oleh Soekarno.

Kedua, hijrah dari demokrasi liberal menuju Musyawarah Mufakat, seperti yang tercantum pada Pancasila sila keempat. Founding Fathers kita jelas sekali lebih mengedepankan musyawarah mufakat dalam keterwakilan, untuk memilih pemimpin negeri ini, baik eksekutif maupun legislatif. Namun lihatlah apa yang dilakukan Indonesia sekarang, Pemilihan Umum dilakukan dengan dasar banyak-banyakan suara dan uang untuk menjadi pemenang. Belum lagi, sila ketiga, Persatuan Indonesia juga menghilang karena diterapkannya sistem otonomi daerah, keterpisahan ini akhirnya menciptakan kompetisi di daerah sampai pusat dan pada akhirnya memicu beberapa wilayah menuntut kemerdekaan.

Ketiga, hijrah dari ekonomi neoliberal menuju ekonomi kerakyatan berkeadilan sosial sebagaimana yang ada pada Sila Kelima Pancasila. Yang terjadi di Indonesia kini identik dengan ukuran-ukuran kuantitatif seperti pertumbuhan ekonomi, inflasi, anggaran defisit, nilai uang, harga minyak dunia, serta menganut politik ekonomi yang tersistem pasar bebas dan korporasi. Pertumbuhan ekonomi ini justru menggiring kita kepada jebakan pasar bebas bernama MEA, yaitu dengan umpan efisiensi sehingga kita tega mempekerjakan orang luar negeri daripada dari bangsa sendiri. Utang luar negeri juga membuat kita kehilangan kuasa dalam pengaturan subsidi dan proteksi pasar nasional. Koperasi pun ikut dilucuti saat amandemen UUD 1945 pasal 33. Padahal daripada membangun Korporasi Multi Nasional, kita seharusnya membangun Koperasi Multi Nasional.

Keempat, hijrah kebudayaan menuju manusia yang beradab karena kini manusia Indonesia telah kehilangan akar budaya sebagai dampak globalisasi. Muncullah manusia-manusia hedon, sekuler, dan berorientasi barat cetakan Sistem Pendidikan Nasional. Tujuan mulia pendidikan nasional tidak dibarengi implementasinya. Mulai dari kurikulum sampai dengan buku yang dipakai masih terjebak pada pola pikir Liberalisme sehingga manusianyapun diarahkan untuk mengikuti Barat. Padahal kitalah yang dikenal dengan kekayaan budaya dan seharusnya menjadi pusat peradaban. Seharusnya semua dirancang untuk penyadaran bahwa kita berbudaya dan akan menjadi pusat peradaban dunia, bukan yang lain. Ditambah lagi dunia pendidikan yang seharusnya tidak memisahkan ilmu agama dan ilmu dunia, sehingga kurikulum seharusnya dirombak total.

Hijrah Kebangkitan Nasional ini baru langkah awal dari gerakan keuamatan untuk memenuhi Hadits Nabi yaitu 100 tahun kebangkitan Mujtahid yang mengubah sejarah. Tahun 624 merupakan tonggak awal kemenangan Umat Islam dalam Perang Badar. Pada tahun 724, Bani Umayyah mencapai puncak dari kekuatan Peradaban Islam Pertama melalui Yazid, penerus Umar bin Abdul Aziz, melalui perubahan ilmu pengetahuan. Pada pola seratus tahun selanjutnya, 824, simbol puncak kekuasaan dunia tercapai pada masa Khalifah Al Ma'mun. Di Indonesia, pada tahun 1524, 
Demak sebagai representasi Kesultanan Islam meraih kejayaan melalui Sultan Trenggono. Pada tahun 1924, HOS Tjokroaminoto, berhasil menggalang kekuatan Ummat Islam yang terdiri dari Islam Tradisional (yang kemudian menjadi Nahdlatul Ulama), Muhammadiyah, dan kelompok Islam lainnya dalam satu Kongres Al Islam Ketiga, yang tiga tahun kemudian terbentuk sebuah kesatuan dari keseluruhan gerakan bernama Perhimpunan Politik-Politik Kebangsaan Indonesia, dari ummat untuk bangsa yang merdeka. Pola seratus tahun sebagai Pembaharu (Mujtahid) ini diharapkan mengarah pada Konsolidasi Kebangsaan 2024. Indonesia harus percaya dan mampu berdiri di atas kaki sendiri! Hari ini kita meneriakkan pada dunia bahwa Indonesia menggenggam kuat zelfbestuur kesemestaan bertauhid, Pemerintahan Sendiri yang Kokoh untuk menyongsong Semesta Bertauhid, sebagai makna Pancasila yang sejati. Layaknya Pak Tjokro di masa lalu yang membangkitkan semangat Zelfbestuur, maka pada zaman ini kita selayaknya meneruskan perjuangan beliau melalui mosi berikut ini.

MOSI KEBANGKITAN NASIONAL BARU

BERJIWA JANG OETAMA YANG SELALU HIDUP melalui

Nasionalisme Kesemestaan Bertauhid Menjadi bagian

\#TjokrountukIndonesia. Bangkitlah untuk negeri, kini dan masa depan.

Karena, kita tidak sedang bertaruh untuk:

Menjadi bebek-bebek peradaban, pengikut arus deras bak sampah dan kotoran.

Berebut kuasa (politik), pendidikan, sosial, hukum, menjalankan ekonomi, dan aksi lain.

Aksi yang hanya "menetes" kepada rakyat negeri,

Tanpa ruh kebudayaan asali seperti sedang berlangsung hari-hari ini.

Aksi yang teori dan praktiknya didatangkan

Dari negeri yang kita sendiri tak faham nilai dan mentalitas perancangnya.

Mari membawa negeri berkebudayaan,

Bernilai kebaikan asali, utk seluruh aksi negeri, kini dan masa depan.

Aksi berjati diri menggunakan nilai dan gagasan

Dari garis darah nusantara sendiri, itulah Kemandirian.

Jangan Pernah Jadi Buih di Lautan

Jadilah Ombak yang Menggulung di Lautan.

Jangan Pernah (hanya) Jadi Pembawa Obor Negeri Orang

Jadilah Pembuat Cahaya Mercusuar Negeri Sendiri.

\section{SIMPULAN}

Berawal kesadaran untuk menelusuri ruh Buku Hidup, yaitu Jang Oetama, penulis mengulik kehidupan HOS Tjokroaminoto yang mampu 


\section{Jang oetama yang ....}

Mulawarman, A. D.

menjadi pejuang rakyat, padahal beliau adalah seorang ningrat. Beliau melakukan empat langkah yaitu politik konsolidasi organisasi, gerakan sosial-ekonomi, penyebaran ideologi sosialisme Islam, dan melakukan gerakan relasional. Semangat dan kejuangan Pak Tjokro tercermin dalam kata Hijrah dan Zelfbestuur. Untuk mencapai Zelfbestuur, jalan hijrah yang harus ditempuh bangsa ini meliputi Sejarah, Demokrasi, Ekonomi, dan Kebudayaan untuk mengembalikan menjadikan Indonesia menjadi Pusat Peradaban Dunia, bukannya berkiblat pada negara lain. Meneladani Pak Tjokro yang menggerakkan semangat melalui pidato di acara besar, maka kini penulis membuat mosi berjudul Kebangkitan Nasional Baru Berjiwa Jang Oetama yang Selalu Hidup. Diharapkan tulisan ini melengkapi dan semakin mengidupkan buku Jang Oetama.

\section{DAFTAR PUSTAKA}

Lowensteyn, P. (2005). Indonesia Between 1908 and 1928. Retrieved September 14, 2019, from https://www.lowensteyn.com/indonesia/sarekat.html\#70

Maarif, A. S. (2006). Islam dan Pancasila sebagai Dasar Negara: Studi tentang Perdebatan dalam Konstituante. Jakarta: Penerbit LP3ES.

Soeharto, P., \& Ihzan, Z. (1981). Cahaya di Kegelapan: Capita Selecta Kedua Boedi Oetomo dan Sarekat Islam Perumbuhannya dalam Dokumen Asli. Jakarta: Penerbit Jayasakti.

Tirtoprodjo, S. (1961). Sejarah Pergerakan Nasional Indonesia. Jakarta: Penerbit Hasta Mitra.

Tjokroaminoto, H. O. S. (1958). Tafsir Program Asas dan Program Tandhim Partai Syarikat Islam Indonesia. Jakarta: Putjuk Pimpinan PSII. 